\title{
Response to extreme conditions in coastal areas: biological tags in flatfish otoliths
}

\author{
Rüdiger Berghahn* \\ Umweltbundesamt, Institut für Wasser-, Boden- und Lufthygiene, Versuchsfeld Marienfelde, Schichauweg 58, \\ 12307 Berlin, Germany
}

\begin{abstract}
More than 3000 juvenile flatfishes from 118 different locations along the coasts of the North Sea were checked for biological tags (hyaline zones) surrounding the nucleus (primordium + larval phase) of their otoliths. All flounder Platichthys flesus specimens had developed such tags in their otoliths. In contrast, tags were rarely found in sole Solea solea. Many North Sea plaice Pleuronectes platessa from subpopulations inhabiting areas with extended tidal flats had pronounced hyaline zones, but lacked these tags along sandy beaches without tidal flats. In long bights with low water exchange in the German Wadden Sea and in the inner parts of the Westerschelde, multiple hyaline zones were frequently found in the otoliths of 0 -group plaice. In previous investigations, it had been possible to experimentally induce early hyaline zones surrounding the nucleus of plaice otoliths by UV-B radiation, high temperature, or starvation treatment. In this study, strong indications are presented that UV$B$ mediated oxidative stress (hydrogen peroxide) in coastal areas, particularly in tidal pools during the pool-dwelling period of the 3 species, was the most important mechanism in the formation of the early hyaline zones in both the field and the laboratory. The occurrence or lack of hyaline zones surrounding the nucleus can be explained by the different patterns in settlement of the 3 species, by the prevailing weather conditions during and after settlement, and by differences in the hydrographic conditions. In the Dutch Wadden Sea, the lack of such early hyaline zones can be attributed to the lower tidal range and the weather conditions during the period of settlement. Due to their highly rheotactic behaviour. early flounder postlarvae almost exclusively inhabit tidal pools directly at the shoreline. Until the tide comes in, flounder may also be exposed to radiation much longer than plaice, since plaice are much more widespread over the tidal flats, depending on the prevailing tidal regime. For sole, tidal pools are less important habitats as compared to plaice and flounder. The distinct multiple hyaline zones in 0 group plaice otoliths are most likely also linked to oxidative stress. Other possible factors like diseases and injuries during the sorting out of by-catch on shrimp vessels are discussed.
\end{abstract}

KEY WORDS: Pleuronectes platessa - Platichthys fiesus $\cdot$ Solea solea Tidal flats - Environmental stress - UV-B radiation · Hydrogen peroxide - Otoliths · Biological tags

\section{INTRODUCTION}

During 12 yr of research in the German Wadden Sea (eastern North Sea) pronounced single or multiple hyaline zones (transparent when viewed on a dark background under a stereomicroscope) have been detected in the otoliths of part of the 0-group plaice Pleuronectes platessa L., flounder Platichthys flesus L., and sole Solea solea L. population in the Wadden Sea

•E-mail: ruediger.berghahn@uba.de proper (Berghahn 1989). Otolith microstructure analysis indicated that the first zone surrounding the nucleus (primordium + larval phase) is deposited on hot, cloudless days during the pool-dwelling mode of life on the tidal flats immediately after settling. On these days, water temperature in the residual waters may exceed lethal limits. In this case, the survivors attempt to flee from the pools through the drainage gulleys on the tidal flats towards the subtidal. From these mass escapes on, pool-dwellers can no longer be found in the residual waters until the settling of new larvae (Berghahn 1983). Some of the survivors tend to 
stay in the subtidal permanently while the rest start to exhibit tidally phased feeding migrations from the subtidal onto the submerged tidal flats (Berghahn 1986).

In the laboratory, hyaline formations in otoliths can be induced artificially by doses of 50 to $100 \mathrm{~mJ} \mathrm{~cm}^{-2}$ of $U V-B$ radiation ( 280 to $320 \mathrm{~nm}$ ), and to a much lesser degree by a rapid increase in water temperature or by starvation (Berghahn \& Karakiri 1990). Further investigations yielded newly metamorphosed plaice and sole in tidal pools which had indeed suffered epidermal skin trauma from solar radiation at cumulative doses of $66 \mathrm{~mJ} \mathrm{~cm}{ }^{-2}$ (Berghahn et al. 1993). Since no early hyaline zones could be found in plaice which had settled along the sandy beach at the border of the Wadden Sea to the open North Sea rather than on the tidal flats, the challenge was taken to study the formation of tags under different geographic conditions and to test the hypothesis that early hyaline formation is linked to radiation operating during the pool-dwelling period. For that reason, otoliths of 0-group plaice from samples taken in summer and autumn 1988 along the North Sea coast from northern Germany to Scotland were checked for tags. Furthermore, it was attempted to relate the findings to the prevailing topographical and hydrographical conditions, namely to the occurrence and habitat quality of tidal pools, and to climatic conditions.

\section{MATERIAL AND METHODS}

Sampling stations in the shallow sublittoral were distributed over the coasts of the North Sea (Fig. 1). In the North Frisian part of the Wadden Sea (eastern North Sea) samples were obtained from the by-catch of shrimpers (Berghahn 1986) Samples from beam trawl catches of research cruises at the other stations were provided by the scientists listed in the acknowledgements. Table 1 gives a description of the various sites with regard to the hypothesis in question. For comparison, some specimens were also caught in the Baltic Sea with a beach seine at the beach of Laboe close to Kiel (Germany). Samples from Red Warf Bay (UK, Irish Sea), from Oban (UK, Irish Sea, taken in 1986) and from the western Dutch Wadden Sea taken in 1986 were also included.

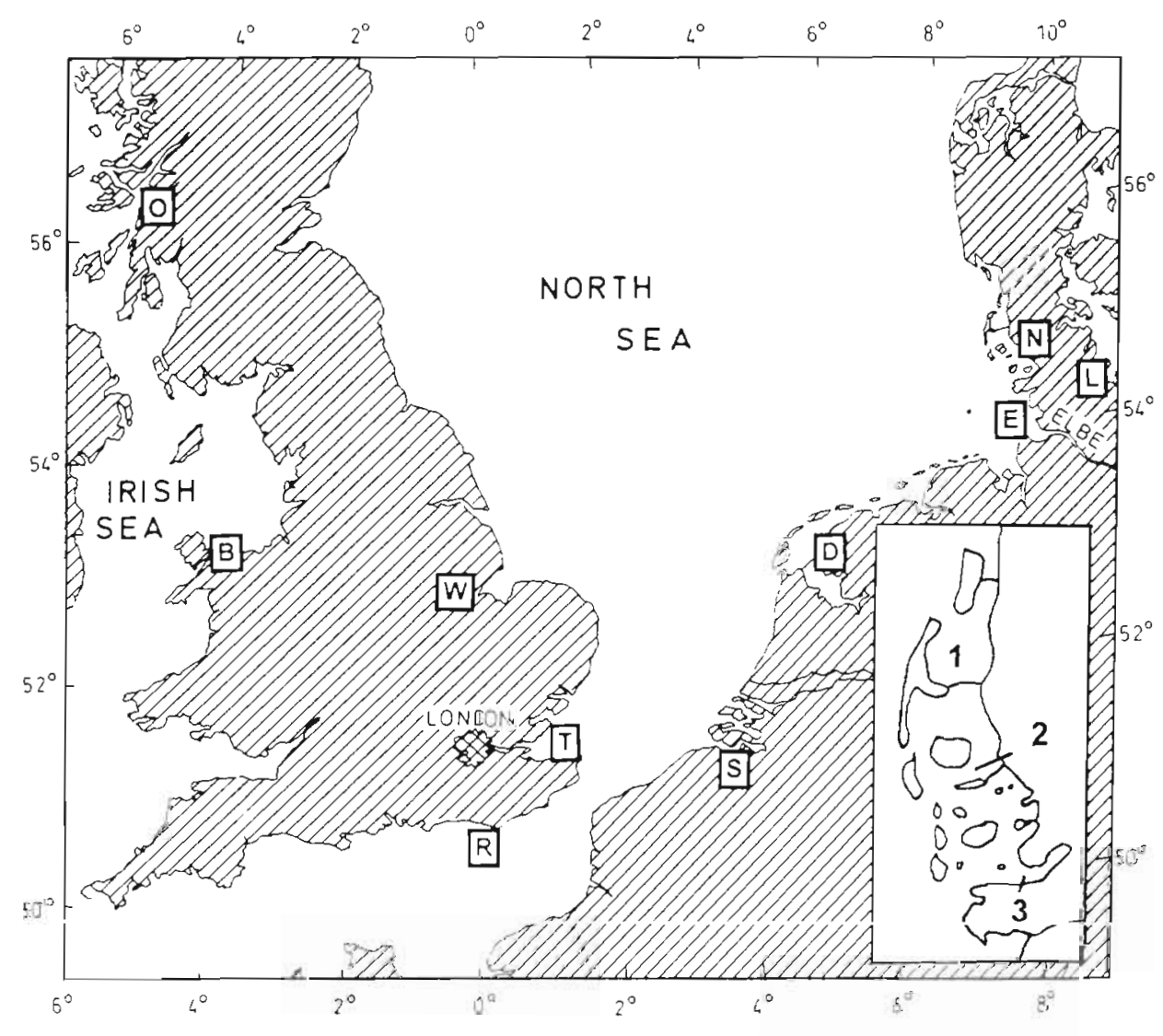

Fig. 1. Sampling sites. $N=$ North Frisian Wadden Sea, $L=$ Laboe (Baltic Sea). $E=$ Elbe estuary,$D=D$ utch Wadden Sea, $S=$ Westerschelde estuary, $R=$ Rye Bay, $T=$ Thames estuary, $W=$ the Wash $B=R$ Red Wharf Bay, $O=$ Oban, inset: Details of sampling site $N$. 1 = Romo-Sylt lagoon, 2 = Norderaue, 3 = Heverstrom 
Table 1 Sampling sites (see also Fig. 1). Mean tidal ranges are given in parentheses

\section{N North Frisian Wadden Sea (Germany)}

51 stations in the subtidal of this extensive tidal flat area including the man-made lagoon $(1.8 \mathrm{~m})$ between the islands Rømø (Denmark) and Sylt (Germany), the tidal stream system Norderaue (2.6$2.8 \mathrm{~m})$ and Heverstrom $(2.9-3.5 \mathrm{~m})$

E Elbe estuary

3 stations from Neuwerk to Cuxhaven $(3.0 \mathrm{~m})$

\section{Dutch Wadden Sea}

49 stations in the subtidal of this extensive tidal flat area from the Dollard (Ems estuary) $(3.2 \mathrm{~m})$ to the island Texel $(1.5 \mathrm{~m})$

S Westerschelde estuary

12 stations from the mouth

$(3.5 \mathrm{~m})$ to Zandvliet $(4.6 \mathrm{~m})$

R Rye Bay

1 station at the sandy beach in the English

Channel $(3.0 \mathrm{~m})$

T Thames estuary

1 station $(4.3-5.3 \mathrm{~m})$

W The Wash

1 station in the subtidal of the only area with extensive tidal flats on the coast of the British Isles $(4.8-5.0 \mathrm{~m})$

L Laboe, Kiel

1 station at the sandy beach (ca $0.25 \mathrm{~m}$ )

B Red Wharf Bay

1 station, $8 \times 1 \mathrm{~km}$ tidal sand flat $(6.4 \mathrm{~m})$

O Oban

1 station at the sandy beach sampled in $1986(2.1 \mathrm{~m})$

Immediately after the catch, all specimens were anaestheized in tricain methanosulfonate and either fixed directly in $96 \%$ alcohol or deep frozen or fixed in buffered formalin and transferred to $96 \%$ ethanol a few weeks later. For examination, otoliths were removed under a stereomicroscope, cleaned and rinsed in $96 \%$ ethanol and embedded on a dark background in epoxy resin, which also served as a clearing medium. Otoliths were viewed under a stereomicroscope in reflected light.

\section{RESULTS}

In 1988, otoliths of 0 -group flatfish (2814 plaice, 103 flounder, 231 sole) from 121 sampling stations (Table 1) were analysed. On 29 June, 4 wk after the end of the settling period, most of the 0 -group plaice specimens sampled in the inner parts of the North Frisian Wadden Sea had a pronounced hyaline zone in their otoliths. These zones must have been deposited a few days after settling, since they were, as in previous otolith microstructure studies, almost adjacent to the accessory primordia, which are formed during the transition to a bottom-dwelling mode of life. The percentage of specimens with hyaline zones in the otoliths decreased towards the border of the Wadden Sea (Fig. 2). In the Elbe estuary, the precentage in September was much lower (Fig. 3) as was the case in the Dutch Wadden Sea (Fig. 4). There were no hot spots in distribution patterns in the Dutch Wadden Sea apart from the station Osterom close to the island Terschelling $\left(58^{\circ} 21^{\prime} \mathrm{N}, 5^{\circ}\right.$ $20^{\prime} \mathrm{E}$ ) with 5 out of 11 plaice juveniles having such a tag in the otoliths. 0-group plaice sampled in June 1986 in the western Dutch Wadden Sea close to the island Texel $(\mathrm{N}=17)$ had no early hyaline zone in the otoliths either, whereas the only flatfish that had such a tag was a 0 -group flounder which had been misidentified as a plaice during sampling. In the same season in 1988, however, specimens with an early hyaline zone were again abundant in the inner parts of the Westerschelde (Fig. 4), with a gradient towards the sea as observed in the Elbe estuary and the North Frisian Wadden Sea. Along the coast of the British Isles, the highest abundance of 0 -group plaice with an early hyaline zone in the otoliths was observed in the Wash,

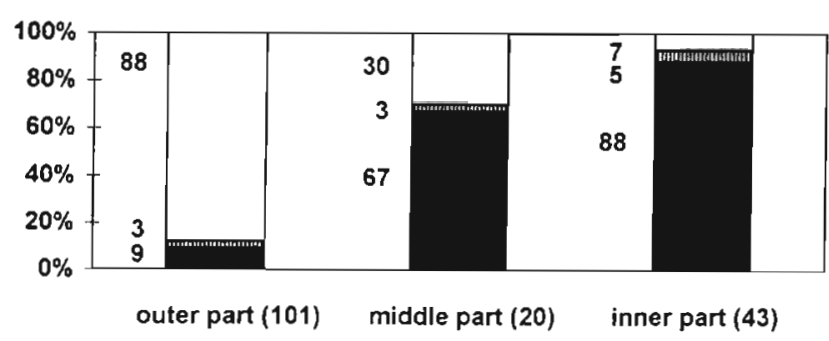

Fig. 2. Percentage of 0 -group plaice with early hyaline zones in the otoliths in the Heverstrom (North Frisian Wadden Sea). Number of specimens is given in parentheses. Black = hyaline zones distinct, striped = hyaline zones weak, white = no early hyaline zone

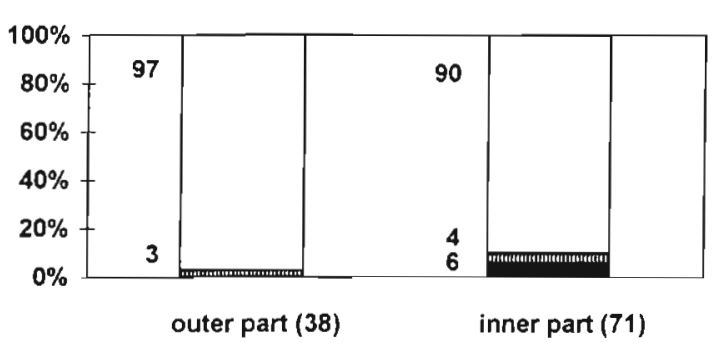

Fig. 3. Percentage of 0 -group plaice with early hyaline zones in the otoliths in the Elbe estuary. Number of specimens is given in parentheses. Black = hyaline zones distinct, striped $=$ hyaline zones weak, white = no early hyaline zone 


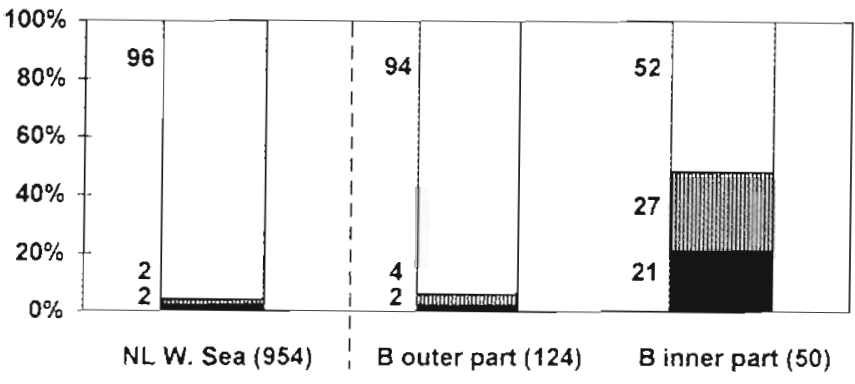

Fig. 4. Percentage of 0-group plaice with early hyaline zones in the otoliths in the Dutch Wadden Sea (NL) and the Westerschelde estuary (B). Number of specimens is given in parentheses. Black $=$ hyaline zones distinct, striped $=$ hyaline zones weak, white $=$ no early hyaline zone

followed by the Thames estuary (Fig. 5). Hardly any of these tags were found in specimens from Rye Bay and in the otoliths of the 50 plaice (0-group) sampled at the beach in Oban. In Red Wharf Bay, 1 plaice (0-group) out of 45 had an early hyaline zone in the otoliths. In the Baltic Sea, the proportion was 5 out of 32 specimens. The seaward gradient in the North Frisian Wadden Sea became less pronounced in the course of the season (Fig. 6)

Analysis of the weather data (Table 2) showed that during peak settlement of plaice in the Dutch Wadden Sea in 1988 (29 March until 15 May, see Karakiri et al. 1991) there had been 5 almost cloudless days in the western part of the Dutch Wadden Sea with the tidal flats exposed to the sun (Table 2 ), but there were moderate winds blowing

All flounder specimens sampled had developed tags in the otoliths. In contrast, tags were rarely found in sole.

Regardless of the occurrence of an early hyaline zone close to the secondary primordia, 1 to 3 further hyaline zones could frequently be found in the otoliths of 0 -group plaice, resulting in up to 4 rings. These sec-

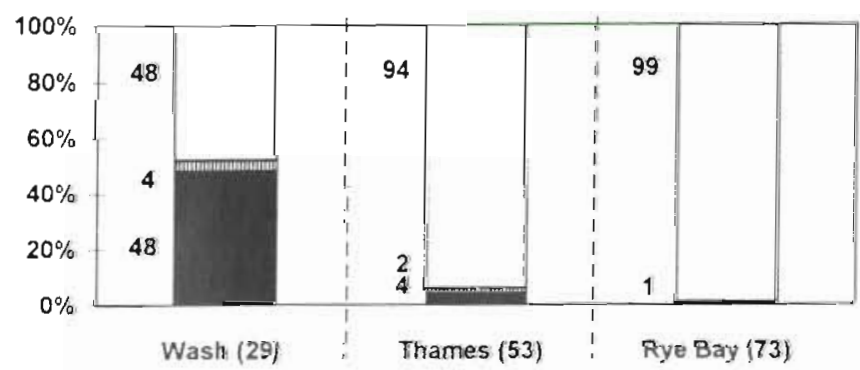

Fig. 5. Percentage of 0-group plaice with early hyaline zones in the otoliths at the North Sea coast of the British Isles. Num. ber of specimens is given in parentheses. Black = hyaline zones distinct, striped = hyaline zones weak, white = no early hyaline zone

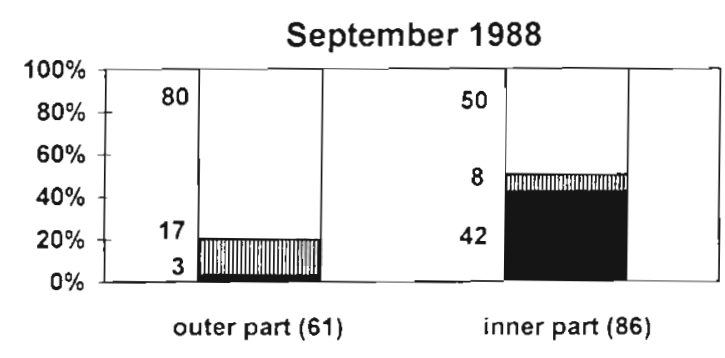

December 1988

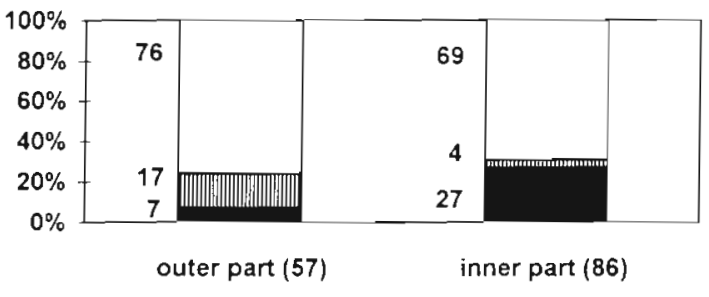

March 1989

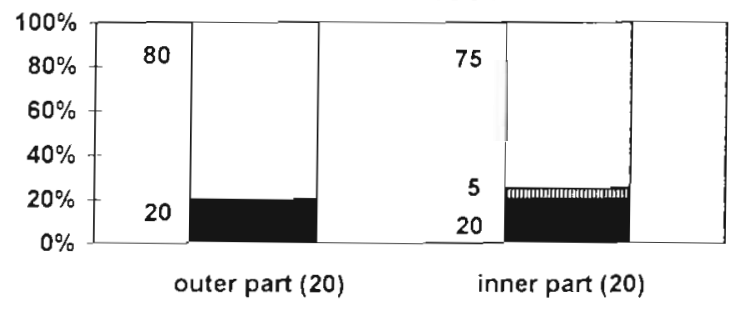

Fig. 6. Changes in the percentage of 0-group plaice with early hyaline zones in the otoliths in the Norderaue tidal stream system (North Friswa Wadden Sea). Number of specimens is given in parentheses. Black = hyaline zones distinct, striped $=$ hyaline zones weak, white $=$ no early byaline zone

Table 2. Perinds of prolonged sunshine, low water, and wind in the Dutch Wadden Sea in spring 1988. Selected data from Anonymous (1988a, b)

\begin{tabular}{|c|c|c|c|}
\hline Date & Sunshine $(\mathrm{h})$ & $\begin{array}{l}\text { Low water, } \\
\text { time of day (h) }\end{array}$ & Wind (Bft) \\
\hline \multicolumn{4}{|c|}{ Western part (Den Helder) } \\
\hline 1 Apr 1988 & 10.9 & $13: 40$ & 4 \\
\hline 2 Apr 1988 & 10.9 & $14: 17$ & 3 \\
\hline 12 Apr 1988 & 9.3 & $9: 05$ & 4 \\
\hline 13 Apr 1988 & 9.8 & 10.41 & 4 \\
\hline $14 \mathrm{Apr} 1988$ & 10.3 & 12.00 & 4 \\
\hline \multicolumn{4}{|c|}{ Eastern part (Delfzijl) } \\
\hline 2) Apr 1988 & 119 & 9.3 .5 & 4 \\
\hline $23 \mathrm{Apr} 1988$ & 12.4 & $10: 06$ & 3 \\
\hline 24 Арт 1988 & 12.2 & $11: 43$ & 3 \\
\hline 26 Apr 1988 & 10.3 & $13: 16$ & 3 \\
\hline 27 Apr 1988 & 10.9 & $14: 49$ & 4 \\
\hline 11 May 1988 & 11.7 & $13: 30$ & 3.5 \\
\hline 12 May 1988 & 13.0 & $14: 52$ & 4 \\
\hline
\end{tabular}



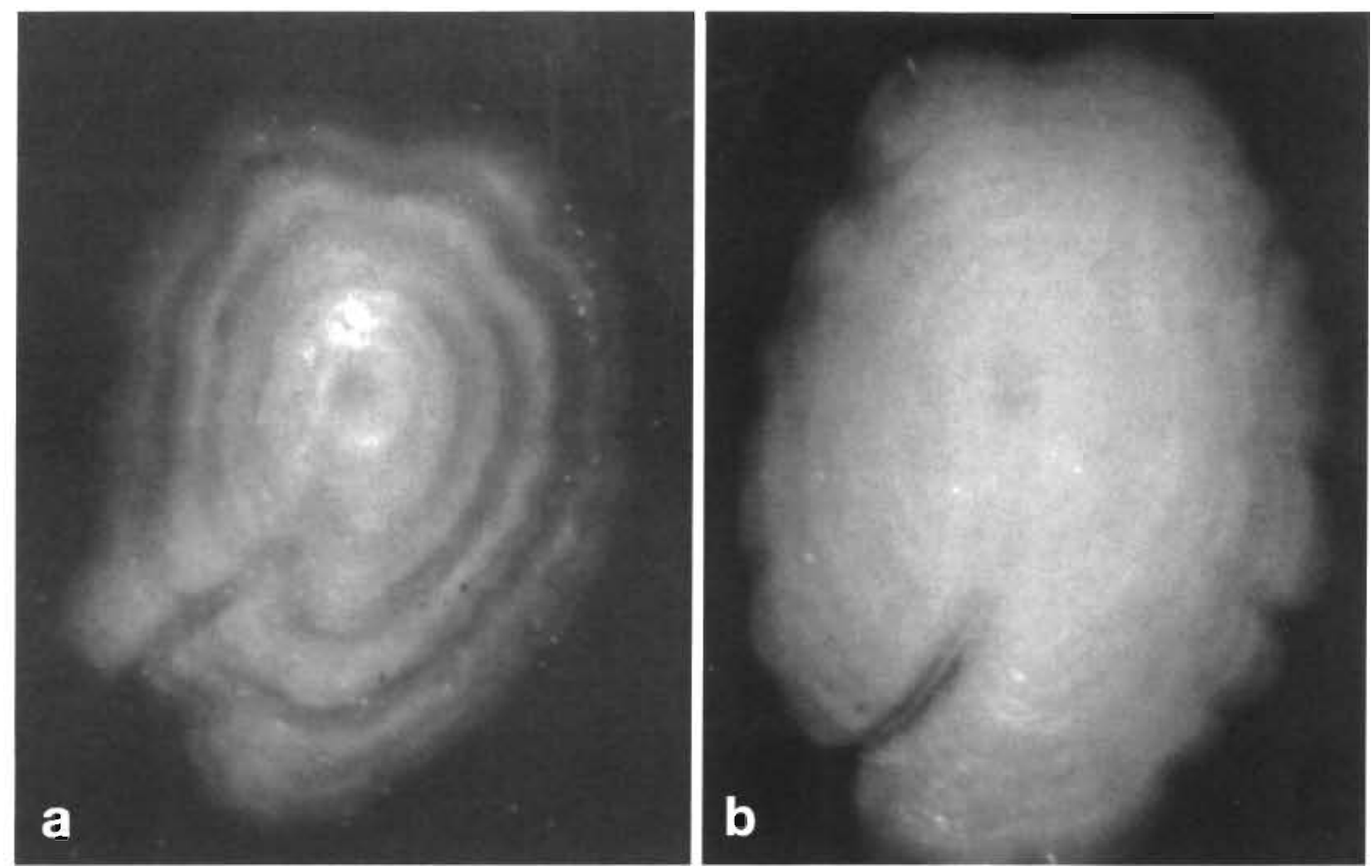

Fig. 7. Pleuronectes platessa. Otoliths of 0-group plaice caught in August 1988 (a) in the man-made lagoon between the islands Rømø and Sylt ( 3 hyaline zones, no early hyaline zone) and (b) at the sandy beach at the border of the North Frisian Wadden Sea (without hyaline zones)

ondary hyaline zones were much more abundant in estuaries and in near-shore areas of long, man-made bights, and were, as in 1989, extraordinarily distinct (Fig. 7) in the man-made lagoon between the islands Rømø and Sylt and in the inner parts of the Heverstrom and the Norderaue tidal stream system (Table 3). The average number of hyaline zones per otolith increased in the course of the season.

Table 3. Percentage of 0 -group plaice with multiple hyaline zones in the otoliths at selected stations in 1988 (see Fig. 1 inset and text). The specimens with a 2 nd, 3 rd and 4 th hyaline zone in the otoliths may lack an early hyaline zone, since they may not have been stressed during the pool-dwelling mode of life

\begin{tabular}{|c|c|c|c|c|c|c|}
\hline \multirow[t]{2}{*}{ Date } & \multirow[t]{2}{*}{ Station } & \multirow[t]{2}{*}{$N$} & \multicolumn{4}{|c|}{ Hyaline zones (\%) } \\
\hline & & & Early & $2 \mathrm{nd}$ & $3 \mathrm{rd}$ & 4 th \\
\hline 29 Jun & $\begin{array}{l}\text { Heverstrom, } \\
\text { inner part }\end{array}$ & 40 & 93 & 44 & 0 & 0 \\
\hline 2 Aug & $\begin{array}{l}\text { Rømø-Sylt lagoon, } \\
\text { close to List harbour }\end{array}$ & 46 & 72 & 35 & 37 & 0 \\
\hline 8 Aug & $\begin{array}{l}\text { Romo-Sylt lagoon, } \\
\text { Lister Ley, outer part }\end{array}$ & 76 & 81 & 32 & 43 & 3 \\
\hline $15 \mathrm{Aug}$ & $\begin{array}{l}\text { Rømø-Sylt lagoon, } \\
\text { Lister Ley, inner part }\end{array}$ & 32 & 66 & 13 & 28 & 16 \\
\hline 25 Sep & Norderaue, inner part & 86 & 42 & 37 & 30 & 5 \\
\hline
\end{tabular}

\section{DISCUSSION}

The much higher abundance of 0-group plaice with an early hyaline zone in the otoliths in areas with extended tidal flats (North Frisian Wadden Sea, the Wash and inner estuaries) fits the hypothesis that in the North Sea these tags are linked to factors operating during the pool-dwelling mode of life. In the Wadden Sea, settling of the large majority of plaice and flounder, as well as part of the 0-group sole population, takes place on the submerged tidal flats (Bergman et al. 1976, Berghahn 1983) as a result of selective tidal transport and the favourable food conditions (Creutzberg et al. 1978). According to Creutzberg \& Fonds (1971) densities of newly metamorphosed plaice are low in the deeper tidal channels of the Wadden Sea. In the Dutch Wadden Sea, however, hardly any tags could be found in this study. In the eastern part of the Dutch Wadden Sea, this might relate to the low mean tidal range $(1.4 \mathrm{~m})$ as compared to the North Frisian Wadden Sea. A low tidal range will not bring the settling larvae to the more elevated flats at a farther distance from the subtidal (see also van der Veer 1986). In this case, pool-dwellers are not exposed to solar radiation and higher water temperature to an extent which could result in the formation of a hyaline zone. This view is also supported by the small sample taken close to the island Texel in 1986. In the Dollard 
(Ems estuary) on the east side of the Dutch Wadden Sea, however, the tidal range is about the same as in the North Frisian Wadden Sea (about $3 \mathrm{~m}$ ). Regardless, in both cases the low rate of early hyaline zones can already be fully explained by the prevailing weather conditions during peak settlement, which occurred between 29 March and 17 April 1988 in the western part and between 29 March and 15 May in the eastern part of the Dutch Wadden Sea (Karakiri et al. 1991) According to the experience gained in former studies, the wind during these days was too strong ( 3 to $4 \mathrm{Bft}$ ) to let high amounts of solar radiation penetrate the water surface (Berghahn 1983, Berghahn et al. 1993). Slight winds may increase the amount of UV-B radiation reflected at the water surface and moderate to strong winds will increase turbidity and thereby strongly reduce UV-B transmission in the residual waters which are inhabited by pool-dwelling flatfish postlarvae and are just a few millimeters to centimeters deep. A complete lack of hyaline zones in 0-group plaice was also observed by Berghahn et al. (1993) in the North Frisian Wadden Sea, but only in 1990. Unlike in the other up to then 8 yr of investigation, no 0-group plaice with an early hyaline zone in the otoliths could be found at 43 stations in the North Frisian Wadden Sea. This was analysed to be due to cloudy conditions during the pool-dwelling period. In other years, the percentage of hyaline zones in otoliths of 0-group plaice was similar to this study. Along the more or less steeply sloping sandy beaches of the British Isles, settlement of plaice occurs at a water depth of appoximately $5 \mathrm{~m}$ (Lockwood 1974) and the shallows are invaded later (Fig. 8, see also Riley 1973 and Gibson et al. 1978). As a consequence, early hyaline zones in the otoliths are rare in these places (Rye Bay, Red Wharf Bay, Oban). The tidal pools even seem to play a minor role for newly settled plaice in Red Wharf Bay, where the tidal muddy sand flats are quite extended (Table 1). The residual waters at low tide along the sand bars and beaches at the border of the wadden Sea are among other things formed only for a short time during low tide, which explains the lack of early hyaline zones at these sites.

The multiple formation of hyaline zones in 0-group plaice as observed in the man-made lagoon between the islands Romø and Sylt raises the question how these later formations are induced. Evidently, calcium deposition in the protein matrix is altered. Theoretically, the causes can be manifnid. Besides high water temperature close to lethal limits, which can occur in the tidal pools (Berghahn 1983), hyaline zones have been demonstrated to be deposited in 0-group plaice after treatment with high levels of LJV-B radiation or after starvation (Berghahn \& Karakiri 1990). Daily ring formation was not disrupted in the hyaline zones. The early hyaline zone in otoliths of 0-group plaice caught in the North Frisian Wadden Sea has been linked to these sorts of environmental stress during the pooldwelling mode of life by means of microstructure analysis (Berghahn 1989, Berghahn et al. 1993). Another factor could be rapid salinity changes in tidal pools during heavy rainfall.

Regarding the mechanisms of formation, one might consider open lesions due to radiation damage as reported by Berghahn et al. (1993) to result in osmotic stress that requires calcium levels above normal conditions. In fish, calcium is taken up via the gills and is brought to the otoliths by the plasma (Simkiss 1974, Campana 1983). Calcium is also taken up from food (Steffens 1985). However, even in freshwater calcium is generally available for teleosts in sufficient amounts, making a direct link of the hyaline zones to calcium concentrations in the plasma unlikely. A likely indirect factor that might reduce mineral deposition in otoliths is the lack of phosphorus ( $E$. Witten, Zoologisches Institut und Zoologisches Museum der Universität Hamburg, pers. comm.). It is almost exclusively taken up from food (Steffens 1985). A decrease in phosphorus levels due to starvation may explain the hyaline zones in plaice otoliths that were experimentally induced by Berghahn \& Karakiri (1990). The specimens treated with high doses of UV-B or high temperature were highly stressed, which may have increased phospho-

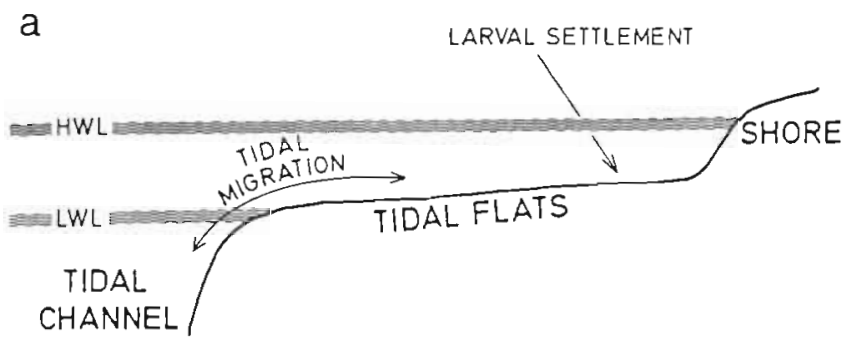

b

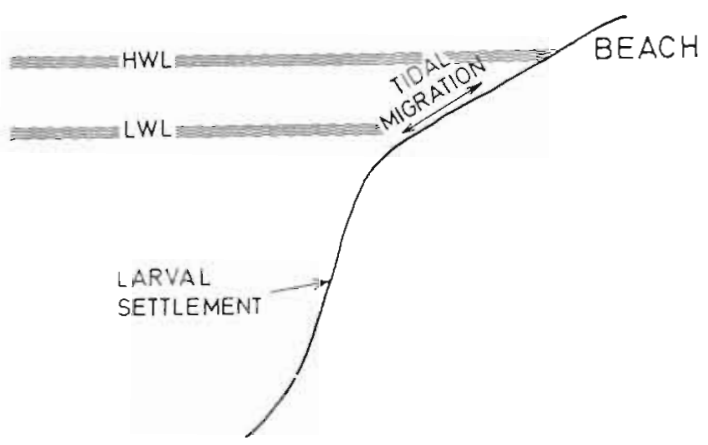

Fig. 8. Areas of settlement and subsequent tidal migration of plaice $(a)$ in the Wadden Sed as compared to (b) the sandy beaches along the British lsles and the sand bars at the border of the Wadden Sea. HWL = high water line, LWL = low water line 
rus demands. In plaice larvae, already moderate UV-B doses can increase non-linear ventilatory responses, indicating sublethal impairments of respiratory control (Freitag et al. 1998). Moreover, the plaice postlarvae in the experiments carried out by Berghahn \& Karakiri (1990) did not take up any food for several days after exposure. However, all this could only explain the formation of the early hyaline zone immediately after settling, since once the pool-dwelling plaice have experienced the extremes they flee towards the subtidal and this yearclass will then no longer be found in tidal pools in the Wadden Sea (Berghahn 1983, Berghahn et al. 1993). In the search for the causes for multiple hyaline zone formation in the highly turbid water of the Wadden Sea, factors other than UV-B radiation and water temperature have to be considered. A complete stop in food uptake for several days was also observed in 0-group plaice specimens, maintained in the laboratory, that had survived the sorting out of the by-catch on board shrimp vessels currently operating in the coastal areas of the North Sea including the Wadden Sea (Berghahn et al. 1992). Sole fisheries are not important in this respect, since they do not operate in these areas (Berghahn \& Vorberg 1998) and have almost $100 \%$ by-catch mortality (van Beek et al. 1990). Depending on conditions during shrimping: a high percentage of 0-group flatfish may survive the sorting procedure (Berghahn et al. 1992). Besides rapid salinity changes in the vicinity of river mouths and stress caused by diseases, injuries during the sorting out of shrimp by-catch (Lüdemann 1993) might be involved in the formation of secondary hyaline zones. However, all these factors do not explain the high abundance of very distinct multiple hyaline zones in the otoliths of 0 -group plaice in the lagoon and the inner parts of the long intertidal bights, since shrimping effort is not higher in these places compared to other parts of the Wadden Sea (Berghahn \& Vorberg 1998) and freshwater inputs from local rivers into the lagoon are negligible. Together with inputs from the atmosphere the latter are less than $0.1 \%$ of the tidal volume (Backhaus et al. 1998).

In more recent publications oxidative stress is considered a very important factor for animals in coastal environments (Abele et al. 1998). This factor can explain both the formation of the early and the secondary hyaline zones. Tidal pools are an ideal place for the UV-driven synthesis of active oxygen species like hydrogen peroxide $\left(\mathrm{H}_{2} \mathrm{O}_{2}\right)$ (Abele-Oeschger et al. 1997). Coastal water and tidal pools, in particular, may contain high levels of dissolved organic carbon (DOC), which is excited by photoactivation and thereby involved in the electron transfer to dissolved molecular oxygen and the formation of $\mathrm{H}_{2} \mathrm{O}_{2}$. Photoactivation is not temperature dependent (Abele-Oeschger et al.
1997). On windless days, the turbid Wadden Sea water in the tidal pools becomes clear in a few minutes (Berghahn 1983), light may then easily penetrate the water column (Berghahn et al. 1993), and in summer $\mathrm{H}_{2} \mathrm{O}_{2}$ concentrations in tidal pools of the Wadden Sea may reach $4500 \mathrm{nmol} \mathrm{l}^{-1}$ (Abele-Oeschger et al. 1997). In laboratory experiments, capitellids Heteromastus filiformis from an intertidal sandflat of the German Wadden Sea have shown an enzymatic response to $\mathrm{H}_{2} \mathrm{O}_{2}$ concentrations of this order of magnitude (Abele et al. 1998). On a cloudy day in May the maximum concentration of $\mathrm{H}_{2} \mathrm{O}_{2}$ was $1690 \mathrm{nmol} \mathrm{l}^{-1}$, although DOC concentrations were between 6000 and $7000 \mu \mathrm{mol} \mathrm{C}$ $\mathrm{I}^{-1}$. Tidal mixing may cause a rapid decrease in $\mathrm{H}_{2} \mathrm{O}_{2}$ concentrations below $300 \mathrm{nmol}^{-1}$ in the Wadden Sea water (Abele-Oeschger et al. 1997). In the German Bight of the North Sea, $\mathrm{H}_{2} \mathrm{O}_{2}$ concentrations are only between 60 and $130 \mathrm{nmol} \mathrm{l}^{-1}$ ( $\mathrm{H}$. Tüg, Alfred-WegenerInstitut für Polar- und Meeresforschung, pers. comm.). Oxygen radicals have been proposed to damage part of the oxygen transport system in plaice larvae, including respiratory proteins and enzymes for aerobic metabolism (Freitag et al. 1998).

Even the unlikely direct effect of calcium levels on hyaline zone formation may be explained by oxidative stress. Active oxygen species are known to increase cytosolic $\mathrm{Ca}^{2+}$. The origin of the increased cytosolic $\mathrm{Ca}^{2+}$ is under discussion; it may be taken up from the extracellular space or released from binding proteins (Suzuki et al. 1997). The latter source is unlikely in plaice, since, in contrast to teleosts with cellular bone (Moss 1962, Persson et al. 1995, Kacem et al. 1998), teleosts with acellular bone, like plaice, do not use their bone as a source of calcium. Bone resorption in the course of calcium deficiencies has only be induced in teleosts with acellular bone under the most extreme and artificial conditions in the laboratory (Weiss \& Watabe 1979, Glowacki et al. 1986, Takagi \& Yamada 1992, 1993). Furthermore, calcium concentration in the plasma of marine fish is reduced to one-third of the concentration in seawater (Bone \& Marshall 1985). AcFcording to Witten (1997) maintenance of juvenile cichlids (acellular bone) in freshwater, seawater and calcium-free water had no observable effect on bone resorption. Bone resorption instead takes place where and when it is necessary for growth (Witten \& Villwock 1997).

It might even be that the experimental induction of hyaline zones in juvenile plaice with UV-B radiation by Berghahn \& Karakiri (1990) was in fact partly or mainly driven by active oxygen species. The seawater used in the experiments originated from a circulating system, which had accumulated yellow substances (Berghahn \& Karakiri 1990) and had a total organic carbon (TOC)

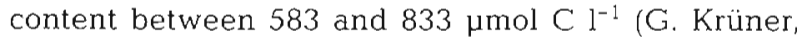
Biologische Anstalt Helgoland, pers. comm.). The water 
in the aquaria was very clear, indicating low particulate organic carbon (POC) concentrations, so the concentrations of DOC were not much lower than the TOC. In tidal pools, DOC was of the same order of magnitude $\left(430 \pm 60 \mu \mathrm{mol} \mathrm{C} \mathrm{l} \mathrm{C}^{-1}\right.$ in February 1996, Abele-Oeschger et al. 1997)

The formation of multiple hyaline zones may be explained as follows. At the sites where multiple hyaline zones were abundant in 0-group plaice otoliths, tidal mixing and water exchange may be extremely low, in particular on windless days (Lillelund et al. 1985). Moreover, 0-group plaice that have given up the pool-dwelling mode of life and started to exhibit tidally phased feeding migrations from the subtidal onto the submerged flats may still experience high concentrations of $\mathrm{H}_{2} \mathrm{O}_{2}$ on hot and sunny (cloudless) days during both high tide and low tide. At low tide they are concentrated at a water depth around $1 \mathrm{~m}$ at the edges of the tidal channels (Kuipers 1973, Berghahn 1984), where the drainage gulleys bring the water from the tidal pools and puddles to the subtidal (Berghahn 1984). With the rising tide, the tidally migrating plaice can be found in the flooding water at a water depth of only a few centimeters. This way, the plaice juveniles may again experience high concentrations of active oxygen species. In June, about $90 \%$ of 0 -group plaice in the Wadden Sea belong to the tidally migrating subpopulation, whereas $10 \%$ tend to stay in the subtidal permanently (Berghahn 1986). In the course of the season, more and more 0-group plaice cease tidal migration and join the subtidal subpopulation on their way to the open North Sea.

In the Baltic Sea at Laboe, the tidal range is only $0.25 \mathrm{~m}$. On calm days, the turbidity close to the shore is low. The latitude is about the same as the North Frisian wadden Sea and the distance is only $80 \mathrm{~km}$, resulting in a comparable light regime. Light penetration is considered to be at least as high as in the tidal pools in the Wadden Sea. DOC in coastal zones of the Baltic Sea

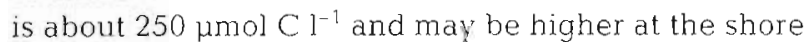
(K. Nagel, Institut für Ostseeforschung, RostockWarnemünde, pers. comm.) or close to river mouths. Under these conditions, the formation of early hyaline zones in very shallow water is not surprising.

In contrast to North Sea plaice and sole, early hyaline zones occurred regularly in otoliths of 0-group flounder. Due to their highly rheotactic behaviour, early flounder postlarvae almost exclusively inhabit itual pows directy at the shorchne (Borghahn 1083). Until the tide comes in, flounders may also be exposed to radiation on average much longer than plaice, since plaice are much more widespread over the tidal flats; depending on the prevailing tidal regime. Furthermore, flounder are in general exposed to much greater fluctuations in salinity than plaice, since they tend to migrate upstream into the rivers. In the settling period, newly metamorphosed sole are frequently found in the residual waters on tidal flats in the Wadden Sea (Berghahn 1987). However, for sole tidal pools are less important habitats than for plaice and flounder (Berghahn 1984).

In conclusion, further laboratory studies on hyaline zone formation in the otoliths of 0 -group flatfish, with special emphasis on the impact of $\mathrm{H}_{2} \mathrm{O}_{2}$ on plaice otoliths, and field studies employing otolith microstructure analysis are needed.

Acknowledgements. This study would not have been possible without the following scientists, who kindly provided most of the samples: Michael Kerstan (Institute für Meereskunde Kiel, Germany), Henk van der Veer (Nederlands Instituut voor Onderzoek der Zee. The Netherlands), Adriaan Rijnsdorp (Rijksinstituut voor Visserijonderzoek, The Netherlands), Olivier Hamerlynck (Rijksuniversiteit Gent, Belgium), Richard Millner (MAFF Lowestoft, UK), Robin Gibson (Dunstaffnage Marıne Laboratory, UK), Moshen Alhossaini (University College of North Wales, UK). The manuscript benefitted greatly from discussions with Doris Abele (AlfredWegener-Institut. Germany) and Eckard Witten (Zoologisches Instutut und Zoologisches Museum der Universitat Hamburg, Germany). This study was supported by the Federal Environmental Agency, Environmental Research Plan of the Minster for the Environment, Nature Conservation and Nuclear Safety of the Federal Republic of Germany (Grants $10802085 / 01$ and 10204271 , and by the state of SchleswigHolstein. This is publication no. 169 of the project Ecosystem Research Wadden Sea.

\section{LITERATURE CITED}

Abele D, Großpietsch H, Pötner HO (1998) Temporal fluctuations and spatial gradients of environmental $P_{02}$ temperature, $\mathrm{H}_{2} \mathrm{O}_{2}$ and $\mathrm{H}_{2} \mathrm{~S}$ in its intertidal habitat trigger enzymatic antioxidant protection in the capitellid worm Heteromastus filiformis. Mar Ecol Prog Ser 163:179-191

Abele-Oeschger D, Tüg H. Röttgers R (1997) Dynamics of UVdriven peroxide formation on an intertidal sandflat. Limnol Oceanogr 42(6): 1406-1415

Anonymous (1988a) Maandoverzicht van het weer in Nederland April 1988. Konink Neder Meteorol Inst De Bilt 85(4): $1-10$

Anonymous (1988b) Maandoverzicht van het weer in Nederland April 1988. Konink Neder Meteorol Jnst De Bilt 85(5): $1-10$

Backhaus J, Hartke D, Hübner U, Lohse H, Müller A (1998) Hydrography and climate of the List tidal basin. In: Gätje Ch, Reise K (eds) Okosystem Wattenmeer. Austausch-, Transport- und Stoffumwandlungsprozesse. Springer, Berlin, p 39-54 (in German)

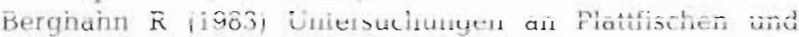
Nordseegarnelen (Crangon (rangon) im Eulitoral des Wattenmeeres nach dem Ubergang zum Bodenleben. Helgoländer Meeresunters 36:163-181

Berghahn R (1984) Zeitliche und räumliche Koexistenz ausgewahlter Fisch- und Krebsarten im Wattenmeer unter Berücksichtiqung von Räuber-Beute-Beziehungen und Nahrungskonkurrenz. PhD thesis, Univ Hamburg 
Berghahn R (1986) Determining abundance, distribution, and mortality of 0-group plaice (Pleuronectes platessa L.) in the Wadden Sea. J Appl Ichthyol 2:11-22

Berghahn R (1.987) The Wadden Sea as a nursery for fish and crustacean species. In: Tougaard $S$, Asbirk $S$ (eds) Proceedings of the 5 th International Wadden Sea Symposium, Esbjerg, Denmark. The National Forest and Nature Agency and The Museum of Fishery and Shipping, Esbjerg, p 69-85

Berghahn R (1989) Environmentally induced biological tags in otoliths of 0 -group plaice (Pleuronectes platessa L.) confirmed by daily increment readings. Rapp PV Rèun Cons Perm Int Explor Mer 191:464

Berghahn R, Karakiri M (1990) Experimental induction of biological tags in otoliths of O-group plaice (Pleuronectes platessa L.) by starvation, temperature, and UV-B radiation. Mar Ecol Prog Ser 67:227-233

Berghahn R, Vorberg R (1998) Shrimp fisheries and nature conservation in the national park 'Wadden Sea of Schleswig-Holstein'-impact, possible conflicts of interests and their prevention. UBA-Texte 82/97, Umweltbundesamt, Berlin

Berghahn R, Waltemath M, Rijnsdorp AD (1992) Mortality of fish from the by-catch of shrimp vessels in the North Sea. J Appl Ichthyol 8:293-306

Berghahn R, Bullock AM, Karakiri M (1993) Effects of solar radiation on the population dynamics of juvenile flatfish in the shallows of the Wadden Sea. J Fish Biol 42:329-345

Bergman M, Kuipers B, Spliethoff P, van der Veer H (1976) Garnalen en krabben als mogelijke predatoren van 0 jarige schol op het balgzand. Visserij 29:432-438

Bone Q, Marshall NB (1.985) Biologie der Fische. Fischer, Stuttgart

Campana SE (1983) Calcium deposition and otol.th check formation during periods of stress in coho salmon (Oncorhynchus kisutch). Comp Biochem Physiol 75A. 215-220

Creutzberg F, Fonds M (1971) The seasonal variation in the distribution of some demersal fish species in the Dutch Wadden Sea. Thalassia Jugos1 7:13-23

Creutzberg F, Eltink AThGW, van Noort GJ (1978) The migration of plaice larvae Pleuronectes platessa into the western Wadden Sea. In: McLusky DS, Berry AJ (eds) Physiology and behaviour of marine organisms. Pergamon Press, Oxford, p 243-251

Freitag JF, Steeger UH, Storz UC, Paul RJ (1998) Sublethal impairment of respiratory control in plaice (Pleuronectes platessa) larvae induced by UV-B radiation, determined using a novel biocybernetical approach. Mar Biol 132:1-8

Gibson RN, Blaxter JHS, de Groot SJ (1978) Developmental changes in the activity rhythms of the plaice (Pleuronectes platessa L.). In: Thorpe JE (ed) Rhythmic activity of fishes. Academic Press, London, p 169-186

Glowacki JK, Cox AO, Sullivan J, Wilkie D, Deftos J (1986) Osteoclasts can be induced in fish having acellular bony skeleton. Proc Nat Acad Sci USA 83:4104-4107

Kacem A, Meunier FJ, Baglinière JL (1998) A quantitative study of morphological and histological changes in the skeleton of Salmo salar during its anadromous migration. J Fish Biol 53:1096-1109

Karakiri M, Berghahn R, van der Veer HW (1991) Variations in settlement and growth of 0 -group plaice (Pleuronectes

Editorial responsibility: Otto Kinne (Editor),

Oldendorf/Luhe, Germany platessa L.) in the Dutch Wadden Sea as determined from otolith microstructure analysis. Neth J Sea Res 27(3/4): $345-351$

Kuipers B (1973) On the tidal migration of young plaice (PIeuronectes platessa) in the Wadden Sea. Neth J Sea Res 6(3): $376-388$

Lillelund K, Berghahn R, Diercking R (1985) Changes in the phosphate content of water in a tidal channel through the Wadden Sea near Nordstrander Bight (eastern North Sea) during a tidal cycle. Int Rev Ges Hydrobiol 70:101-112 (in German)

Lockwood SJ (1974) The settlement, distribution and movements of 0-group plaice, Pleuronectes platessa (L.) in Filey Bay, Yorkshire. J Fish Biol 6:465-477

Lüdemann K (1993) Fishery induced skin injuries in flatfish from the by-catch of shrimpers. Dis Aquat Org 16:127-132

Moss ML (1962) Studies of the acellular bone of teleost fish 2. Response to fracture under normal and acalcemic variations. Acta Anat 48:46-60

Persson P, Takagi Y, Björnsson BT (1995) Tartrate resistant acid phosphatase as a marker for scale resorption in rainbow trout, Oncorhynchus mykiss: effects of estradiol-17b treatment and refeeding. Fish Physiol Biochem 14: $329-339$

Riley JD (1973) Movements of 0-group plaice Pleuronectes platessa L. as shown by latex tagging. J Fish Biol 5: 323-343

Simkiss K (1974) Calcium metabolism of fish in relation to ageing. In: Bagenal TB (ed) Ageing of fish. Unwin Bros Ltd, London, p 1-12

Steffens W (1985) Grundlagen der Fischernährung. Fischer, Jena

Suzuki YJ, Forman HJ, Sevanian A. (1997) Oxidants as stimuIators of signal transduction. Free Radical Biol Med 22(1/2):269-285

Takagi Y, Yamada J (1992) Effects of calcium deprivation on the metabolism a acellular bone in tilapia, Oreochromis niloticus. Comp Biochem Physiol 102A: 481-485

Takagi Y, Yamada J (1993) Changes in the metabolism of acellular bone in tilapia, Oreochromis niloticus, during deficiency and subsequent repletion of calcium. Comp Biochem Physiol 105:459-462

van Beek FA, van Leeuwen PI, Rijnsdorp AD (1990) On the survival of plaice and sole discards in the otter-trawl and beam-trawl fisheries in the North Sea. Neth J Sea Res 26(1): $151-160$

van der Veer HW (1986) Immigration, settlement, and density-dependent mortality of a larval and early postlarval 0 group plaice (Pleuronectes platessa) population in the western Wadden Sea. Mar Ecol Prog Ser 29:223-236

Weiss RE, Watabe $N$ (1979) Studies on the biology of fish bone. III. Ultrastructure of osteogenesis and resorption in osteocytic (cellular) and anosteocytic (acellular) bones. Calcif Tissue Int 28:43-56

Witten PE (1997) Enzyme histochemical characteristics of osteoblasts and mononucleated osteoclasts in a teleost fish with acellular bone (Oreochromis niloticus, Cichlidae). Cell Tissue Res 287:591-599

Witten PE, Villwock W (1997) Growth requires bone resorption at particular skeletal elements in a teleost fish with acellular bone (Oreochromis niloticus, Teleostei: Cichlidae). J Appl Ichthyol 13(4):149-158

Submitted: April 13, 1999; Accepted: July 13, 1999

Proofs received from author(s): December 10, 1999 